\title{
Mercado mundial e imperialismo na perspectiva de Claudia von Braunmühl
}

\author{
World market and imperialism in the perspective \\ of Claudia von Braunmühl
}

DOI: 10.5752/P.2317-773X.2017v5.n3.p22

1. Professor de Direito e Relações Internacionais na UFRRJ. Coordenador do Curso de Relações Internacionais da UFRRJ. Autor do livro Imperialismo, Estado e Relações Internacionais, pela Editora Ideias e Letras. Integrante do Grupo de Trabalho da CLACSO Pensamento Jurídico Crítico. Contato: luizfelipe.osorio@gmail.com. ORCID: https://orcid.org/0000-0001-6058-7809

\section{Luiz Felipe Brandão Osório}

Recebido em: 01 de junho de 2017.

Aceito em: 16 de agosto de 2017.

\section{RESUMO}

O conceito de imperialismo celebra seu jubileu centenário em uma condição mais atual do que nunca. Ante as transformações internacionais e a crise de acumulação do capitalismo que assola o sistema de Estados, nada mais necessário do que se retomar e aprofundar os debates marxistas sobre o tema. Nesse sentido, há que se passar pelo incontornável caminho do Estado e das relações internacionais no capitalismo. Uma discussão por esses meandros atravessa uma atualização das premissas marxianas, tangenciando a compreensão mais contemporânea do marxismo sobre Estado e relações internacionais, até desaguar em uma importante fonte das interpretações de Marx: Claudia von Braunmühl. Em sua perspectiva sobre mercado mundial e imperialismo, a autora traz à baila a configuração política internacional em uma pluralidade de Estados nacionais, em permanente competição, como marco estrutural para a manutenção e reprodução das relações de produção capitalistas, servindo, portanto, de alicerce para a compreensão basilar do imperialismo.

Palavras-chave: Imperialismo. Marxismo. Mercado mundial. Braunmühl. Capitalismo.

\begin{abstract}
The concept of imperialism celebrates its centennial jubilee in a more current condition than ever before. Faced with international transformations and the accumulation crisis of capitalism that plagues the whole system of States, it is pivotal to return to and deepen the Marxist debates on this subject. In this way, we have to go through the inescapable path of dealing with State and international relations in capitalism. A discussion of these aspects goes through an updating of Marxian basis and the more contemporary understanding of Marxism over State and international relations, until it emerges in an important source of Marx's interpretations: Claudia von Braunmühl. In her perspective on world market and imperialism, the author brings to the fore the international political configuration in a plurality of national States, in a dynamic of constant competition, as a structural framework for the maintenance and reproduction of capitalist production relations, as well as serving as a foundation for the fundamental comprehension of imperialism.
\end{abstract}

Keywords: Imperialism. Marxism. World market. Braunmühl. Capitalism. 
Introdução

Claudia von Braunmühl ${ }^{2}$ inscreve-se no rol de autores de Relações Internacionais que precisam ser urgentemente e necessariamente resgatados, em meio à premente busca por alternativas teóricas para as tarefas de compreensão do mundo contemporâneo. E quando se evoca a original e pioneira ${ }^{3}$ interface entre Marx, marxismo e a ciência internacionalista a menção à alemã é imperiosa. Não só pelo que representa o papel central da mulher no desenvolvimento das ideias políticas, mas, especificamente, pelo conhecimento que difunde sobre relações internacionais, marxismo e imperialismo.

Dentro da fértil e crítica década de 1970, temperada por lutas, protestos, radicalizações e pela encruzilhada das teorias marxistas sobre o Estado, é possível apontar a produção intelectual de Braunmühl no debate da derivação do Estado, mais especialmente em um ramo que se instaurou e correu paralelamente e entrelaçadamente: o debate (alemão) do mercado mundial ${ }^{4}$. Mesmo inserida nessa corrente, ela diferencia-se de seus pares ao salpicar a discussão com elementos da teoria materialista do Estado, construindo sua articulação teórica e inaugurando a visão materialista do imperialismo.

O início de suas reflexões deu-se, por uma série de razões, sendo duas delas a afinidade intelectual e a proximidade pessoal a Joachim Hirsch $^{5}$ por meio do grupo de trabalho que compunham dentro da área de Ciências Sociais da Goethe-Universität, na cidade de Frankfurt am Main $^{6}$, Braunmühl chama para si a responsabilidade da reflexão sobre o imperialismo por essa perspectiva. Os dois autores, em especial, dentro desse conjunto, destacam-se pelo projeto de pesquisa sobre o planejamento científico estatal da República Federal da Alemanha, financiado pela Fundação Volkswagen (Volkswagenstiftung), que impulsionou as publicações da autora na direção das Relações Internacionais ${ }^{7}$.

Nesse ponto vem a contribuição de Braunmühl para a teoria marxista do Estado e para as Relações Internacionais, principalmente. Até então aqueles que se dedicavam à teoria marxista do Estado relegavam a esfera interacional de acumulação, tomando o Estado-nação, a economia nacional ou o capital nacional como ponto de partida. A cientista política alemã é a destacada ao insistir que o nível analítico apropriado para a compreensão do Estado é o mercado mundial ${ }^{8}$. É na dimensão internacional da acumulação, no mercado mundial que se deve derivar ou determinar a forma do Estado burguês. Acumulação, reprodução e expansão do capital não podem ficar aprisionadas às fronteiras nacionais (FAY; STUCKER, 1980).

Também não há razões para se estabelecer a identidade entre Estado e capital, haja vista que o capital (internacional) é organizado e particularizado pelo Estado, dentro de fronteiras nacionais, ganhando a forma de capital nacional, em meio a peculiaridades históricas das lutas sociais. Dessa maneira, a compreensão plena do Estado e do capitalismo passa pelas relações internacionais como um todo. A forma mercado mundial é o modo de existência das relações nacionais; estas subsistem em e por meio das relações do mercado mundial, logo este não é um elemento externo às nações, mas sua base e sua atmosfera vital (BONEFELD, 2013).
2. Cientista política. Lecionou nas universidades de Berlin e Bielefeld, sendo laureada com o título de professora emérita da Universidade Livre de Berlim. Após anos de envolvimento com as relações internacionais, Estado e imperialismo, redirecionou seus estudos às questões de gênero e de governança.

3. É possível identificar por suas obras excertos esparsos que tratam de mercado mundial, monopólios e competição, bem como da expansão do capitalismo pelo mundo, com maior ênfase, desde o Manifesto Comunista (1848), que escreveu com Engels, passando pelos Grundrisse (1857-1858) e, mais claramente, nos Tomos I e III d'0 Capital (1867 e 1894), sem relegar completamente outras obras. Sem falar nos debates da Segunda Internacional e nas discussões carreadas pelos teóricos pioneiros (clássicos) do imperialismo.

4. Muito em virtude da autora, o debate (alemão) do mercado mundial não ficou restrito aos limites fronteiriços germânicos, tendo ganhado o mundo, notadamente quando incorporado pelas pulsantes discussões marxistas britânicas. Nessa toada, destacam-se autores, notadamente do marxismo britânico (Open Marxism), que não têm o imperialismo como eixo prioritário de suas análises, mas que, ao tratar da teoria do Estado, remetem às concepções marxianas de mercado mundial para compreender as relações internacionais, como Barker (1991); Clarke (1991); e Bonefeld (2013).

5. É atualmente professor emérito de Ciência Política da Universidade Johann-Wolgang-Goethe-Universität em Frankfurt am Main. Acadêmico de grande envergadura intelectual, Hirsch foi um dos principais expoentes do debate derivacionista, resistindo às pressões e ao tempo como um de seus poucos baluartes. Seu pensamento ultrapassou as fronteiras da Alemanha, tendo influenciado autores por todo o mundo: Altvater e Hoffmann (1990), Caldas (2015), Carnoy (1994), Clarke (1991), Holloway e icciotto (1978), Jessop (1982) e Mascaro (2013).

6. Altvater e Hoffmann (1990) chama os pesquisadores reunidos de Grupo de Frankfurt, que, além de Hirsch e von Braunmühl, contava com a presença de expoentes, como von Auw, von Cappelleveen, Engelhardt, Fichtner, Gloede, Mayer, Wilker, Wolf, Köhler e Küchler.

7. Tanto no primeiro artigo, de 1973 , quanto no terceiro, de 1976, há referências claras ao projeto de pesquisa. Não coincidentemente, os três artigos de Braunmühl aqui citados aparecem em publicações que também carregam escritos de Hirsch. 
8. Obviamente aqui não podemos desconsiderar o pioneirismo e o brilhantismo das análises de Wallerstein, de Frank, de Dos Santos e de Amin sobre a reconstrução da história do capitalismo como um sistema mundial e o modo de produção capitalista como um processo de acumulação mundial. 0 que se enfatiza na visão de Braunmühl é o pensamento sobre a teoria marxista do Estado sob os cânones do mercado mundial.

9. Nachtwey e Ten Brink (2008) lamentam tanto 0 fato de 0 debate ter se perdido no tempo, que escreveram um artigo reverenciando e resgatando

o tema, o qual é a referência citada, quanto os três ensaios de Braunmühl não terem se tornado uma obra singular, mas terem ficado esparsos em artigos.

10. Alegoria utilizada por Hirsch (2002) no sentido de retomar as lições decorrentes da década de 1970.

11. A divisão proposta do Elbe (2010) do pensamento marxista tem seu primeiro viés chamado de marxismo tradicional, cujo marco temporal estabelecido vai de 1878 em diante até a consolidação da União Soviética. Os expoentes teóricos são, dentre outros, em uma primeira geração, Engels (que ao mesmo tempo é fundador e seguidor do marxismo) Kautsky, Bernstein, Lafargue, Mehring, Bebel e Plekhanov; e em sua segunda geração, com Lênin, Trostky, Luxemburgo, Bukharin, Hilferding e Adler. A referência central teórica são os textos políticos de Marx e de Engels (Anti-Dühring e A origem da família, da propriedade privada e do Estado), uma vez que à época não eram todas as obras marxianas que haviam sido publicadas.

É a leitura canônica de Engels que funda esta tradição. Sua interpretação volta-se para a orientação das práticas revolucionárias. 0 Estado é visto como aparato do domínio da burguesia, devendo ser tomado pelos trabalhadores rumo à transição ao socialismo. Nesse sentido, Lênin emerge como grande tributário da corrente.
O centro nevrálgico é: o Estado não existe no singular, mas apenas na forma de um sistema de Estados nacionais. Ela argumenta que a dinâmica ilustrada entre Estado e capital não é resultado do desenvolvimento moderno do capitalismo ou do que se veio a chamar de globalização, mas é inerente da própria forma nacional do Estado, a qual deve ser derivada do mercado mundial, âmbito da manifestação plena do modo de produção capitalista, de contexto marcado forçosamente por dois aspectos: pela acumulação global capitalista (essencialmente contraditória) e pelo sistema internacional de Estados (plural e concorrencial).

Não obstante a fecundidade de suas premissas, a alemã, no auge do debate do mercado mundial, limitou-se, todavia, a três ensaios específicos sobre o tema das relações internacionais (BRAUNMÜHL, 1973, 1974, 1976), redirecionando suas pesquisas a partir da década de 1980 para outras searas das ciências sociais. A despeito de seu destino ter seguido a tendência à entropia, atinente a todo o debate da derivação do Estado e do mercado mundial, arquivados com a guinada neoliberal dada pelo sistema internacional, as ideias da autora persistiram pelo tempo e resistiram às dificuldades, podendo, agora, ser resgatadas 9 .

Desse modo, caberá a este artigo uma breve contextualização de Braunmühl nos debates da derivação do Estado e do mercado mundial, para, então, avançar nas suas formulações quanto ao mercado mundial e suas contribuições sobre o imperialismo.

Em meio à crise mundial de acumulação do capitalismo e à insuficiência das leituras tradicionais em Relações Internacionais para decifrar os desdobramentos mundiais, cumpre acordar os cachorros mortos ${ }^{10}$, ou seja, retomar as ideias radicais, alicerçadas nos pressupostos marxianos, para a plena compreensão do modo de produção capitalista. O que significa: perpassar nomeadamente a dinâmica que o molda, o imperialismo.

0 debate da derivação do estado

A releitura de Marx a partir d' O Capital realizada na década de 1960 inaugurou mais uma inflexão dentro do círculo teórico marxista. Se os clássicos (pioneiros) ${ }^{11}$, intérpretes imediatos do pensamento marxiano, enfatizaram a matriz economicista e o marxismo ocidental ${ }^{12}$ redirecionou os olhares para os elementos políticos e filosóficos da superestrutura $^{13}$, o movimento de resgate das raízes marxianas emerge como uma reação às interpretações anteriores, buscando extrair das categorias da economia política e da própria forma do capital e das relações de produção capitalistas, o entendimento das estruturas políticas que lhe são próprias. Pela crítica das formas sociais é que se manifesta a essência do capitalismo.

A nova leitura do marxismo é tida, conforme Elbe (2010), a partir de 1965. Com fulcro no Marx da maturidade, apropria-se dos Grundrisse e d'O Capital v.1 e das categorias econômicas nele anunciadas, como arcabouço para a construção de uma teoria política crítica do capitalismo ${ }^{14}$. O caminho que será ressaltado se direciona por meio da retomada da economia política ${ }^{15}$ e do resgate do horizonte teórico do Estado, dados na República Federal da Alemanha, o debate da derivação do Estado (Staat- 
sableitungsdebatte), o qual reposicionou a compreensão teórica e política do Estado e do capitalismo no tempo presente.

O vocábulo derivação advém do substantivo Ableitung, da língua alemã, o que não significa que haja uma simples determinação, sendo o Estado mero resultado da vontade da classe dominante, mas, sim, de um determinado modo de produção e das relações sociais que lhe são inerentes e diferenciadoras dos modos anteriores. Daí o estudo da especificidade do Estado no capitalismo (CALDAS, 2015). Nesse diapasão, a teoria da derivação representa um caminho de superação aos impasses políticos. No seio das contradições extremas do capitalismo desenvolvido de bem-estar social e da já entrevista crise da experiência soviética, o marxismo avança para compreender o Estado a partir das categorias que estruturam a sociedade capitalista ${ }^{16}$.

Logo, as categorias desenvolvidas n'O Capital, como mais-valor, valor, acumulação, lucro, preço, salário, não servem apenas para o debate econômico específico, mas são essenciais para uma discussão ampla, também política, pois são categorias histórico-materialistas desenvolvidas para iluminar a estrutura de classes na sociedade capitalista e as formas e concepções gerais dessa estrutura (HOLLOWAY; PICCIOTTO, 1978). A crítica à economia política operada por Marx é condensada na noção de que as categorias econômicas são a aparência de formas fetichizadas das relações sociais. Assim, os conceitos não serão estritamente políticos ou econômicos, mas capazes de apreender criticamente o conteúdo das formas política e econômica das relações sociais. Cumpre, portanto, a compreensão do Estado e da política a partir de sua derivação da categoria de capital. Em outras palavras, o eixo fundamental dessas análises é a ênfase na necessidade de explicar a separação entre as esferas da política e a da economia pela perspectiva do capital.

Os autores axiais calcam sua argumentação na formulação de estratégias políticas e modos de organização da classe trabalhadora, com fulcro no desenvolvimento do movimento trabalhista na história, pautados pela bifurcação entre reformismo e revolução. Nessa toada, a chegada ao socialismo se daria por caminhos distintos, ou por reformas institucionais e legais ou pela insurreição da classe trabalhadora, uma vez que a via estatal é inerentemente obstaculizada. Cada qual se embasa em perspectivas opostas no tocante ao papel do Estado. Entre o capitalismo monopolista de Estado $\left(\right.$ Stamokap) ${ }^{17}$, cuja elaboração teórica aponta a atuação do aparato estatal direcionada a atender as demandas da acumulação de capital e o capitalismo tardio (Spätkapitalismus) ou teoria da socialdemocracia de Estado $^{18}$, defensor da segregação da política da análise da acumulação de capital, o debate alemão da derivação do Estado oferece alternativas.

A saída dessa encruzilhada passa pelo entendimento pleno da forma política estatal, o que não é um exercício simples. O Estado burguês ganha especificidade como uma entidade fora e, ao mesmo tempo, ao lado da sociedade burguesa. A concentração da sociedade na forma estatal, que se coloca externa a ela mesma, parecendo flutuar sobre sua própria existência, é fulcral, pois somente assim pode garantir a manutenção e a reprodução da sociedade capitalista, âmbito internamente contraditório permeado pelas relações de produção. Com efeito, a relação entre
12. A indicação geográfica não é precisa, mas serve para diferenciar as vertentes marxistas desenvolvidas, notadamente, no pós-Segunda Guerra Mundial. 0 marxismo ocidental é aquele mais afeto a fins acadêmicos e reformistas e menos às práticas revolucionárias. Esse posicionamento manifesta-se contrário à experiência soviética, tendo seu lastro teórico nas obras do jovem Marx, da fase que em o intelectual alemão modulava seu pensamento, cujos textos não haviam sido publicados antes da guerra. 0 que se convencionou chamar de marxismo oriental é também geograficamente impreciso, serve, porém, de contraponto ao ocidental na medida em que reflete o pensamento marxista voltado aos fins de luta revolucionária, próximo às experiências soviética, chinesa e cubana. Para mais Anderson (2004).

13. Segundo Elbe (2010), o segundo pilar toca o chamado marxismo ocidental, que abrange o interregno de 1923 até cerca de meados da década de 1960. Tendo os textos do jovem Marx como referência teórica, a saber: Teses sobre Feuerbach, Manuscritos Econômicos-Filosóficos de 1844, A Questão Judaica e A Ideologia Alemã; esta divisão se ramifica em diversos autores espalhados em variados países. Desde Lukács, Kosik, Korsch, Bloch, Lefebvre, até os intelectuais que compõem a chamada Escola de Frankfurt, os da Escola Italiana (como Gramsci e Galvano della Volpe), o Grupo lugoslavo e a Escola Húngara. O liame teórico que vincula a todos são as ideias de tarefas, urgências e debates em torno das revoluções socialistas e, sobretudo, das circunstâncias das reformas do próprio capitalismo, dada sua persistência em novos patamares. Em suas teorizações é possível encontrar indícios do humanismo e da valoração da subjetividade, conforme presente nos escritos iniciais de Marx. 0 foco dessas abordagens reside muito mais na autonomia dos elementos superestruturais em relação sua base econômica, destacando as nuances da política, do direito e da ideologia como aspectos transformadores.

14. Entre os prenunciadores estão Pachukanis e Rubin. 0 ponto de partida é a leitura de Althusser, que reverberou desdobramentos teóricos em diversos países, como Alemanha, Inglaterra e França. Com divergências internas, mas com muitas convergências, solidificaram interpretações acerca do Estado e do capitalismo. Esse universo que se descortina é tão amplo que é possível tecer inúmeras subdivisões e classificações, o que, definitivamente, não caberá a esta pesquisa. Um estudo aprofundado sobre o debate da derivação do Estado é encontrado em Caldas (2015). 
15. 0 debate da derivação do Estado consegue estabelecer-se mediante a crítica materialista da tentativa da burguesia de discutir a economia isoladamente no tocante à relação exploratória de classes em que ela se funda (HOLLOWAY; PICCIOTTO, 1978)

16. É nesse cerne que, desde 0 artigo cardial de Müller e Neusüss, Die Sozialstaatsillusion und der Widerspruch von Lohnarbeit und Kapital, de 1970 publicado pela revista PROKLA no ano seguinte, as visões derivacionistas do

Estado gravitam em torno(tanto para abraçá-lo quanto para rechaçá-lo). Acrônimo do termo em alemão Probleme des Klassenkampfs, o periódico que carrega no nome os problemas da luta de classes é uma publicação de vanguarda que resiste bravamente ao tempo e à maré contrária. Criada em 1971, em meio ao contexto de ebulição do final dos anos

1960 e da crise que se avizinhava na

década seguinte, a revista crítica de ciências sociais consolidou-se com um baluarte dos estudos radicais. Contou com a colaboração de importantes figuras marxistas e foi o vetor primordial para a difusão dos debates derivacionis tas, sendo responsável pelo artigo que inaugurou as discussões em sua edição pioneira.

17. A ortodoxa teoria marxista embasa-se na identificação do Estado com os interesses do capital, na medida em que ocorre uma verdadeira fusão da esfera política na econômica. Essa vertente era defendida, em geral, pelos partidos comunistas do mundo alinhados à União

Soviética. As bases desse pensamen-

to situavam-se na historicidade do momento específico que identificava a revolução não apenas como um movimento possível, mas provável, tendo em vista 0 acirramento das contradições do capitalismo. A dinâmica de desenvolvimento das forças produtivas produziria a contradição inconciliável entre as forças produtivas e as formas sociais de produção. Ademais, levaria ao amálgama que se constituía entre Estado e capital monopolista, em meio à confusão de interesses, 0 que aumentaria a resistência social dos excluídos desse bloco monolítico. Para mais ver: Altvater e Hoffmann (1990), Bonnet (2007), Caldas (2015), Carnoy (1994), Clarke ( 1991) e Holloway e Picciotto (1978). economia e política não requer ser pensada pela dinâmica entre estrutura e superestrutura, mas o ponto nodal está no motivo pelo qual as relações sociais em uma sociedade burguesa aparecem em formas separadas, como relações políticas e relações econômicas. O Estado precisa ser visto enquanto forma específica de uma dominação histórica de classe (MÜLLER; NEUSÜSS, 1971).

$\mathrm{O}$ artigo de Müller e Neusüss inspirou e carreou uma geração de pensadores, que se ocuparam de uma ampla releitura do marxismo a partir dos aspectos essenciais da sociedade capitalista. Inicialmente, constando na obra organizada conjuntamente por Holloway e Picciotto, as primeiras respostas vieram de Altvater, Hirsch, Blanke, Jürgens, Kastendiek, Gerstenberg, Reichelt e Braunmühl, tendo cada qual assumido uma ênfase específica ${ }^{19}$. A tendência foi o alargamento do debate, não apenas pela Alemanha, mas por outros países europeus. Conforme mapeado por Altvater e Hoffmann (1990), Bonnet (2007), Caldas (2015) e Gerstenberg (2010), os expoentes dessa corrente advém dos círculos universitários, majoritariamente da Alemanha, notadamente de Berlim e de Frankfurt am Main, interconectados com outros França e Inglaterra.

Dentre as variadas vertentes que se apresentam nesse universo, caberá ênfase específica àquela voltada, mormente, à discussão das relações internacionais e, consequentemente, do imperialismo.

\section{0 debate (alemão) do mercado mundial}

Dentro do debate da derivação do Estado, paralelamente, como um tópico basilar na compreensão do Estado e da política a partir das categorias econômicas marxianas do capital, emerge como um tema crucial na análise via teoria materialista do Estado o mercado mundial. Desde os primeiros escritos de Marx, a tendência expansionista do capital é enfatizada. O desenvolvimento histórico do capitalismo (e do imperialismo) comprova a imprescindibilidade de sua abordagem para uma ampla compreensão. O esgarçamento do capitalismo ocorre por meio e, ao mesmo tempo, resulta na forma mais desenvolvida do capitalismo, o mercado mundial. Em meio aos impasses da década de 1970, a necessidade de retorno às raízes marxianas atingiu a concepção de mercado mundial, captado como ponto essencial na acumulação capitalista.

Especialmente, no caso alemão, a inserção internacional e a estrutura social nacional estimulam o aprofundamento do tema. No contexto da Guerra do Vietnã, e a consequente contestação da hegemonia estadunidense, e das incertezas econômicas, pela crise do sistema monetário-financeiro, com o rompimento dos Acordos de Bretton Woods, pululam as análises acerca do mercado mundial. Na Alemanha Ocidental verificou-se a efervescência de ideias sobre aquele momento de inflexão no capitalismo pelo globo. Isso não aconteceu nesse país fortuitamente. Tendo em vista sua posição peculiar no sistema interestatal do pós-Segunda Guerra, a República Federal da Alemanha de inimigo de guerra foi içada à categoria de parceiro estratégico, recebendo apoio material direto e indireto para sua recuperação econômica. Desenvolvida à convite, a economia germânica foi alicerçada no comércio internacional, o qual passou a responder por par- 
cela significativa de seu produto interno bruto. Destarte, vulnerável às crises externas, as desilusões com o arranjo do pós-guerra são descortinadas. Após de uma década de célere crescimento econômico, a economia política alemã revelava seu real caráter, reformista, conciliatório e não transformador, apoiada em um Estado de segurança que fomenta o compromisso de classes e a manutenção do capitalismo. Logo, passou-se à investigação das entranhas do capitalismo em terras germânicas.

$\mathrm{Na}$ radiografia marxista do Estado, Christel Neusüss ${ }^{20}$, Klaus Busch $^{21}$ e Claudia von Braunmühl desenvolveram suas interpretações acerca das relações internacionais, partindo das premissas derivacionistas. Nelas a releitura da crítica à economia política trazia a tendência inerente de internacionalização do capital para aspectos nodais da discussão por saídas à esquerda. Suas formulações teóricas ficaram conhecidas como debate do mercado mundial (Weltmarktdebatte) ${ }^{22}$. O liame que os unifica as teorias do mercado mundial é a base derivacionista do resgate da análise da teoria da forma-valor (Wertformanalyse) para explicitar a separação constitutiva entre Estado e capital. Essa clivagem entre esfera política e econômica, e a relativa autonomia do Estado dela decorrente, são elementos estruturantes próprios da forma política do capitalismo, sem os quais resta inviabilizada a reprodução das relações de produção capitalistas. O mercado mundial é a manifestação mais completa e desenvolvida do movimento do capital ${ }^{23}$, o espaço necessário e fundamental para a compreensão do capital em sua plenitude e do fenômeno político. Os três buscam reconstruir a análise marxiana do capitalismo por meio da descrição e da reflexão teórica sobre como a lei do valor opera no mercado mundial, no qual os processos econômicos ganham vida própria no tocante aos atores envolvidos.

Pode considerar-se mesmo um debate no sentido do confronto de interpretações, visto que, apesar de muitos pontos convergentes, há também divergências significativas entre eles ${ }^{24}$. São na cisão com os dois expoentes que emergem a originalidade das formulações e a relevante contribuição (quanto ao conceito de imperialismo) de Braunmühl às discussões do mercado mundial.

Braunmühl, mercado mundial e imperialismo

O destaque dado a Braunmühl deve-se à abordagem totalizante e inovadora que a contrapõe aos dois baluartes e a inscreve na lacuna da teoria marxista do Estado quanto à dimensão internacional. As esferas nacional e internacional são vistas como um todo, desempenhando a concorrência entre as unidades políticas apartadas e em coletividade (Estado-nação) o papel essencial na dinâmica da lei do valor. Para Braunmühl (1976), boa parte do debate derivacionista perdeu-se nas coreografias da abstração, caindo nas armadilhas instrumentalistas ou funcionalistas que cercaram muitas das discussões dentro desse ramo, como aquelas identificadas com a Escola Lógica do Capital ${ }^{25}$, como no caso de Neusüss (1972) e Busch (1974). Ela defende que não basta derivar a forma política e o Estado das relações sociais capitalistas, mas é fulcral ir além e fomentar o estudo da forma de particularização estatal, de suas especificidades. Se
18. A teoria foca na separação institucional entre Estado e economia, enfatizando a autonomia relativa estatal enquanto instituição política, revigorando a clivagem teórica entre as esferas da produção e da distribuição. Essa percepção foi advogada, em proporções distintas, por frações à direita e à esquerda dentro das socialdemocracias europeias, notadamente. Essa compreensão funda-se na autonomia da política em relação à economia, a qual a teoria da derivação não rechaça, apenas critica a explicação que os autores envolvidos conferem à autonomia $\mathrm{e}$ ao caráter estruturante do Estado na economia capitalista (CALDAS, 2015). Em que pese às diferenças significativas entre si, a Offe e a Habermas é imputada a crença equivocada de que apenas com mudanças fundamentais na forma e no conteúdo dos poderes distributivos do Estado, ou seja, na vontade política, é possível alterar os padrões da sociedade capitalista, sem a necessidade da revolução nas relações de produção. A solução para o atraso do capitalista seria dada pela via política. Para mais ver: Altvater e Hoffmann (1990), Bonnet (2007), Caldas (2015), Carnoy (1994), Clarke, (1991) e Holloway e Picciotto (1978).

19. É Gerstenberg (2010) que faz 0 diagnóstico dos autores divididos por ênfases temáticas.

20. A autora, expoente do derivacionismo, foi uma das mais destacadas economistas política da Alemanha. Viveu e lecionou em Berlim. Nascida em 1937 veio a falecer em 1988, deixando um importante legado teórico e político. Neusüss (1972) sustenta a separação entre as esferas de circulação interna e externa, delineando atuações distintas do Estado em cada âmbito em relação aos capitais. A intervenção de questões não econômicas, que são externas ao movimento dos capitais, é vista como 0 obstáculo que impede a plena realização das tendências econômicas. A modificação da lei do valor pela separação dos Estados em unidades nacionais limitadas por fronteiras é complementada pelo movimento da taxa de câmbio (dinâmica válida apenas para o cenário internacional). 0 circuito de troca mercadoria-dinheiro-mercadoria transmuta-se em mercadoria-dinheiro-divisa-mercadoria no mercado mundial. Ou seja, o câmbio nacional atua diretamente na cadeia da troca mercantil. 
21. 0 autor é professor de estudos europeus na Universidade de Osnabrück. Participou como importante expoente no debate do mercado mundial dedicando-se atualmente a discutir 0 modelo social da União Europeia e suas contradições. Busch (1974) aproxima-se consideravelmente das perspectivas de Neusüss, complementando-a mediante 0 entendimento do mercado mundial enquanto um âmbito que reúne

a combinação de diferentes esferas nacionais de circulação, com a tendência de formação de um capital social total nacional que compete com seus congêneres internacionalmente. Em suma, repete a dualidade das esferas de circulação e a concepção somatória entendendo o mercado mundial como

o total das partes nacionais que 0 compõem, ressaltando a importância dos conglomerados multinacionais e apontando o mercado mundial como fatiado em esferas de circulação nacionais e distintas entre si. Entende que na esfera internacional há um movimento em direção da equalização das taxas de câmbio, que se tornam um mecanismo protetivo para os capitais nacionais, a depender de sua estratégia internacionalizante. Isso leva à possibilidade, inclusive, de países menos desenvolvidos conseguirem constituir setores exportares de excelência na competição internacional.

22. Cabe pontuar que os três autores escolhidos são justificados pelo vínculo ao debate derivacionista e ao entorno intelectual do periódico PROKLA. O destaque dos três não exclui outras eventuais contribuições existentes que por não terem conexão direta com esses cânones, não serão abordadas.

23. Marx (2013) a política modifica a lei do valor, o limite da intervenção estatal não pode ser entendido sem que se tenha em mente os limites da forma nacional do Estado. Não há como apreender as especificidades e a essência estatal sem tocar a forma do Estado-nação, inserido no contexto de acumulação global de capital e no sistema capitalista de Estados, ou seja, o mercado mundial (BRAUNMÜHL, 1976).

Reitera-se que pelo viés marxiano, o mercado mundial apresenta-se como um esquema distinto das relações de produção entre os países (as relações internacionais propriamente ditas, em sentido estrito), uma dimensão mais ampla, em verdade. Não fortuitamente, desde seus primeiros esboços marxianos, o mercado mundial aparece como ponto concluinte da anatomia da sociedade capitalista, visto que é lá onde todas as contradições da sociabilidade burguesa se põem em jogo, manifestando sua mais concreta materialidade (BONEFELD, 2013).

O impulso à fortificação do mercado mundial é dado pela competição entre capitais, que utilizam todos os meios possíveis disponíveis (como a constante reorganização do Estado para garantir condições de valorização) na busca por lucros. Essa dinâmica leva à cristalização de múltiplos centros de acumulação moldados em Estados-nação. Assim como o capital em geral ilustra a contradição entre anarquia (na competição entre capitais) e despotismo (controle dentro de cada capital individual), a cena política carrega também a unidade contraditória entre despotismo (soberania estatal dentro dos territórios nacionais) e anarquia (competição interestatal). O Estado configura-se, por conseguinte, como um vetor privilegiado da competição intracapitalista no mercado mundial. Por isso, ele será atravessado pela contradição entre a tendência à internacionalização dos capitais e à nacionalização da organização capitalista por meio de um sistema político de intervenções estatais nas relações de produção (JESSOP, 1982).

Destarte, a tarefa teórica é descortinar a forma particularizada em que o capital se apresenta, organizada em Estados nacionais, em coletividade e em constante concorrência. Ao invés de partir do capital nacional e seu Estado, a autora analisa o imperialismo dentro da totalidade constitutiva do mercado mundial ${ }^{26}$, o qual não se resulta no somatório das partes, mas um ambiente sistemático, pleno, permeado por categorias e contradições próprias.

Logo, o mercado mundial configura a forma universal de existência capitalista ${ }^{27}$. Nesse espaço, o trabalho humano é levado aos mais elevados níveis de abstração, em termos de enquadramento na constante revolução das relações de produção, na concorrência constante pela valorização do valor. Assim, o mercado mundial constitui em geral a base e a atmosfera vital do modo de produção capitalista de produção, não sendo uma categoria econômica como outras, mas é, ao mesmo tempo, o pressuposto e o resultado da produção capitalista. Por conseguinte, o mercado mundial não é externo às relações nacionais de exploração, mas ele subsiste e fomenta a exploração nos territórios nacionais e por meio do controle político estatal (BONEFELD, 2013). Nessa dinâmica, o Estado capitalista não existe no singular, somente em coletividade (BARKER, 1991). 
Se o capital é inerentemente expansionista e internacional, o mercado mundial é a base necessária para a acumulação primitiva, tendo adquirido com o desenrolar da história papel seminal para a organização da produção e para a circulação de mercadorias e capitais (JESSOP, 1982). A concretude do desenvolvimento histórico comprova que a forma do Estado nacional não pode ser entendida no singular, mas em meio a um sistema coletivo de Estados, o qual é a mola propulsora da acumulação e da reprodução das relações capitalistas por todos os quadrantes do mapa-múndi. Ela inverte o ponto de partida e volta às relações capitalistas, que têm por objeto e por pressuposto o mercado mundial, para a compreensão do Estado e da forma política, enfatizando a necessidade de entender os Estados dentro da teoria do imperialismo, uma vez que o capitalismo nasce como um sistema global alavancado pelo imperialismo (KÁN, 2013).

Ao teorizar sobre o imperialismo, dentro desta esfera totalizante do mercado mundial, em um primeiro e específico esforço, Braunmühl (1973) delineia as linhas mestras do conceito: é dos alicerces político e econômico do mercado mundial que se deriva a compreensão estrutural do imperialismo. Logo, a autora diferenciava-se radicalmente do pano de fundo até então costurado pelas visões teóricas acerca do tema ${ }^{28}$. Logo, são de suas estruturas que devem ser extraídos e explicados os fenômenos como a forma do Estado e do imperialismo, o que ela se debruça a fazer nos seguintes (BRAUNMÜHL, 1974, 1976, 1978, 1983). Nesse diapasão, em suas palavras, o imperialismo somente pode ser conceituado adequadamente como uma forma específica do capitalismo, como manifestações de estágios históricos no desenvolvimento concreto das leis de movimento do capital. Os fenômenos empiricamente constatáveis que caracterizaram as vertentes do imperialismo até então não são por si só suficientes para explicá-lo (BRAUNMÜHL, 1973). Por exemplo, a expansão mundial do capital, a estruturação capitalista do mercado mundial, os monopólios internacionais operantes, a disputa pela divisão do mundo, controle sobre esferas de influência, a crescente disparidade de patrimônio e qualidade de vida, a internacionalização da luta de classes, a crescente contraditoriedade e as mudanças na função do Estado capitalista. Sem perder de vista as especificidades históricas, eles são entendidos como expressões e formas aparentes da dinâmica interna das relações capitalistas e de suas leis de movimento. A despeito das importantes transformações históricas passadas, o capitalismo não perde sua identidade. Ainda que altere sua maquiagem, seu rosto é o mesmo. Portanto, a explicação do imperialismo requer um passo adiante no sentido de sair das armadilhas da aparência e compreender a real natureza do capital.

Destarte, pululam as tarefas de uma teoria do imperialismo derivada da crítica marxiana à economia política. As questões a serem esclarecidas gravitam em torno de: como que a lei do valor se realiza, intermediada pela concorrência na crescente internacionalização do processo de acumulação, e de como a relação intermetropolitana e entre metrópole e periferia se estrutura; em quais formas aparece a exploração no processo de valorização do capital, que é internacional, mas mediado por unidades nacionais; e quais funções o aparato estatal desempenha nesse processo de mutação das formas. Basicamente, o objeto de uma teoria do imperialismo é o desenvolvimento do movimento dos capitais no mercado mundial. Com fulcro nes-
24. Há uma clivagem importante no debate do mercado mundial. De um lado estão Neusüss e Busch e, de outro, Braunmühl (que complementa e, portanto, diferencia sua visão com elementos da teoria materialista do Estado). Para os dois primeiros, a reconstrução da lei do valor marxiana requer ser ampliada também para a esfera internacional. A análise do movimento de capital no mercado mundial não pode ser derivada simplesmente da natureza inerente do capital. É, sim, necessário definir as formas modificadas de valor, a existência nacional-estatal do capital, na qual a lei geral do capital atinge sua inflexão no mercado mundial. A forma modificada do valor é expressa na atuação dos capitais individuais como um conjunto social total e, também, como fragmento unitário que compõe o todo, buscando a mesma taxa de lucro. Nas duas abordagens, destaca-se a visão dos efeitos modificados da lei do valor em função dos capitais nacionais, que são apresentados como individualizados no mercado mundial, os quais se relacionam com outros capitais nacionais. Pode-se afirmar que ambos, com suas visões integracionistas dos capitais, entendem a concorrência (e a anarquia dos mercados) como apenas a aparência, a superfície do mercado mundial e não como um traço constitutivo do modo de produção capitalista. Para mais ver: Bonefeld e Holloway (1991) e Nachtwey e Ten Brink (2008).

25. Caldas (2015), Carnoy (1994), Clarke (1991).

26. A influência de Bukharin (1974; 1986) é notável, nesse sentido, e expressa ao longo de seus escritos, quando recorre frequentemente às ideias do russo.

27. Para o autor, o mercado mundial apresenta-se como a forma universal de existência capitalista. É somente nesse espaço que as indústrias nacionalmente constituídas adquirem seu sustento como indústrias capitalistas. 0 mercado mundial configura o imperativo categórico da produção capitalista dentro das fronteiras nacionais, entre nações e muito além dos limites nacionais (BONEFELD, 2013). 
28. Braunmühl (1973; 1974) afirma que a conceito norteador de imperialismo apresentado pelos pioneiros contém recônditos vícios burgueses. As visões, em geral, pressupõem que o capital nacional, que antes permanecia restrito ao âmbito interno, expande-se e reproduz-se externamente, engendrando o imperialismo. 0 imperialismo tem como premissa a divisão do mercado mundial em Estados nacionais, a qual se manifesta em caráter normativo conferindo legitimidade à acumulação interna de capitais nacionais frente à intervenção de capitais estrangeiros. Ainda, a autora especifica aqueles que defendem 0 teorema do desenvolvimento do subdesenvolvimento, não fazendo grandes distinções dentro do amplo e plural universo das teorias da dependência, colocando autores de diferentes matizes no mesmo balaio crítico. A despeito dessas imprecisões, suas ponderações ambicionam abarcar os teóricos críticos terceiro-mundistas. Em geral, essas perspectivas alargam o objeto de análise para o sistema internacional como um todo. Assim, entendem o surgimento do modo de produção capitalista e sua expansão em escala mundial como um processo de conexões e dimensões internacionais, apontando a sua face perversa como determinante para as mazelas da periferia. Apesar do foco importante, ele é restrito às relações entre centro e periferia que é uma parte do todo mercado mundial, e cuja assimetria é inegável e decorrência necessária no contexto do desenvolvimento capitalista.

29. Não obstante a perspectiva teórica distinta é nodal mencionar aqui o importante estudo de Leite (2017) sobre mercado mundial, imperialismo e teoria do valor.

30. 0 que se verifica na conceituação da autora é a presença da assimetria metrópole e periferia. Sob um viés teórico distinto dos autores terceiro-mundistas, ela não deixa de enfatizar a desigualdade estrutural do sistema capitalista. Diferentemente dos teóricos cepalinos, ela via no Norte interesse pela industrialização parcial e seletiva do Sul. 0 maior exemplo ela ilustra com as políticas de auxílio ao desenvolvimento, muito em voga à época, que, em verdade, mostravam um caráte bem diferente daquele que as anunciava. A apregoada ajuda ao desenvolvimento servia, senão, aos capitais metropolitanos privados em busca de espaços de valorização em detrimento de qualquer interesse coletivo possível do país receptor Em verdade, o mecanismo colaborava com a reestruturação da divisão internacional do trabalho, a favor dos capitais metropolitanos, e assegurava a consolidação de esferas de influência neocoloniais (BRAUNMÜHL, 1973). se alicerce, cumpre dissecar a forma de realização da lei do valor no mercado mundial ${ }^{29} \mathrm{e}$ as funções que desempenha o Estado burguês em relação ao que por ele é designado capital nacional no processo internacionalizado de acumulação. Logo, a interface entre internacionalização da acumulação e forma política nacional é a chave para abrir a essência recôndita do imperialismo. A partir de uma análise concreta e categorial dos processos de acumulação e de crise no contexto do mercado mundial é que se chega a respostas para as constatações empíricas prementes, como as assimetrias incontornáveis entre centro e periferia.

Ela define imperialismo como as formas econômica e política de dependência ${ }^{30}$ e de modulação das condições de vida, oriundas da estruturação do mercado mundial, que é lapidada pelos os imperativos de valorização dos capitais desenvolvidos das metrópoles, que se voltam tendencialmente a abraçar toda produção mundial, e pelas formas de poder político deles resultantes. As estratégias imperialistas envolvem, em maior ou menor medida, a reversão da tendência à queda da taxa de lucros, por meio de importação de matéria prima barata ou exportação de capitais por diversos canais, bem como pela troca desigual. Concomitantemente, a violência estatal, na forma de intervenção militar, pode ser utilizada na empreitada. Nesse diapasão, o mercado mundial tornou-se o espaço da produção e da troca que se constitui em uma pluralidade de Estados.

A partir do pano de fundo que se apresentara até então, o imperialismo atual
pode ser conceituado como as formas política e econômica de dependência e de
modulação das condições de vida, oriundas da estrutura do mercado mundial,
cunhada pelos imperativos de valorização dos capitais metropolitanos, tenden-
cialmente voltados à produção mundial e conectados pelas formas de poder po-
lítico deles resultantes. (BRAUNMÜHL, 1973, p. 59, tradução nossa) ${ }^{31}$.

O imperialismo é a força motriz que impulsiona o sistema capitalista de Estados para sua formação e suas transformações. Em verdade, o conceito de imperialismo precisa ser debatido dentro das dimensões da divisão internacional do trabalho e da luta de classes sob determinação da função historicamente modificada da forma política estatal, assinalando especialmente a gravitação do desenvolvimento específico da divisão internacional do trabalho estruturada pelo capital metropolitano (BRAUNMÜHL, 1973). Em outras palavras, a derivação da forma do imperialismo não ocorre diretamente, logicamente, objetivamente, automaticamente da estrutura do mercado mundial. É extraída, sim, em meio e atravessada pela luta de classes e de grupos, que modulam a divisão internacional do trabalho. Logo, malgrado a luta de classes não ser o elemento cardial da compreensão materialista do imperialismo, ela não deixa de ser relevante, ao contrário, está imersa na dinâmica que confere as particularizações e peculiaridades dos capitais e dos Estados nacionais.

Ao contrário daqueles que estariam presos à jaula de aço das abstrações derivacionistas, admitindo a existência de leis positivistas e idealistas e consequentemente defendendo o curso inerente objetivo da lei do valor (como Neusüss e Busch), ela enfatiza o papel importante que desempenham o sujeito e a luta de classes na modulação dos efeitos da tendência à queda da taxa de lucros. A análise do capitalismo precisa ser guiada por uma teoria da acumulação que tome a luta de classes como um elemento 
sistêmico em constante mobilidade e em processo de mutação, e não como uma decorrência automática da intervenção modificativa da lei do valor.

Em meio à dinâmica de particularizações e transformações, dois elementos estruturantes para a compreensão das formas do imperialismo: a acumulação de capital (e sua contradição inerente) e a organização política específica em uma pluralidade de Estados.

A tarefa de compreensão do sistema imperialista passa, conforme Braunmühl (1974), caracterizada, sobretudo a partir do viés metropolitano, pela contradição entre internacionalização e nacionalização do processo de acumulação. Se mediante a internacionalização da produção, a exploração torna-se cada vez mais internacional; ela continua a ser mediada pela força, a qual é nacionalizada. Atualmente essa tensão manifesta-se pela emergência dos capitais que operam em âmbito global, como as corporações multinacionais, e a permanente intervenção estatal no processo de reprodução do capital. Os capitais, ao mesmo tempo em que transcendem as fronteiras e atuam frequentemente em uma postura contrária aos interesses de seu próprio Estado (e aos seus próprios ou de sua fração), demandam o aparato estatal para que garanta o mínimo de segurança à sua base territorial de domínio, mobilizando, em muitos casos, a intervenção estatal para sua defesa e para a manutenção da organização nacional-estatal do mercado mundial (BRAUNMÜHL, 1976).

Logo, a organização política em uma pluralidade de Estados em concorrência complementa e se mescla ao primeiro aspecto, perfazendo a base da análise. No mercado mundial, a regulação e a repressão necessárias não se condensam em uma unidade centralizadora, mas estão presentes na organização política plural dos Estados. O mercado mundial tem que ser visto como um internacional, estatal-organizado e especificamente estruturado, abrangente, efetivo contexto de competição, dentro do qual o nacional-estatal emerge e consolida a si mesmo e os Estados formam suas estruturas econômicas, sociais e políticas características ${ }^{32}$. No modo de produção capitalista, a dominação é reproduzida no funcionamento dos mecanismos econômicos que ainda precisa da regulação e da repressão políticas e garantidoras, uma vez que a autoridade exercida anarquicamente é incapaz de assegurar adequadamente pela operação das leis de produção. Nessa toada, por mais que a internacionalização das relações de produção esteja em uma trajetória ascendente e que a competição internacional determine com mais intensidade as condições de produção internas, é pela via nacional que a exploração é mediada. A burguesia nacional requer um espaço próprio delimitado para a imposição de seus interesses e para evitar a tendência à equalização dos níveis de produtividade. Nesse sentido, a organização política do mercado mundial em uma coletividade concorrencial de Estado erige o cenário adequado para a constante valorização do valor, mantendo em funcionamento as engrenagens do motor capitalista. Mais do que uma característica, a organização política em multiplicidade de Estados nacionais é uma necessidade para a manutenção e reprodução das relações capitalistas.

Diante do conceito e de seus elementos moduladores, Braunmühl esgarça os limites da compreensão do imperialismo, franqueando mais um caminho para o aprofundamento do estudo.
31. "Vor dem Hintergrund des bislang Dargestellten ist der gegenwärtige Imperialismus zu begreifen als die von den Verwertungsimperativen der fortgeschrittensten Kapitale in den Metropolen bestimmte Strukturierung des Weltmarktes, tendenziell der Weltproduktion, einschliesslich daraus resultierender politischer Herrschaftsformen, Formen der ökonomischen und politischen Abhängigkeit und der Formierung von Lebensverhältnissen".

32. A relação entre mercado mundial $\mathrm{e}$ Estado nacional precisa ser entendida como um contínuo histórico inerente ao capitalismo e ser determinada em referência às leis manifestadas no processo de acumulação do capital, em uma forma específica, concreta e histórica (BRAUNMÜHL, 1976). 
Conclusões

33. Nessa linha, coube a Barker (1991), no cenário britânico, tecer acompanhamentos e complementos ao raciocínio. Ele também insiste que a análise da forma estatal deve partir do capital em geral ao nível do mercado mundial. Diferentemente de Braunmühl, Barker (1991) não retoma a formação histórica dos Estados, mas enfatiza que cada espaço nacional representa a fusão de uma fração particular do capital mundial com segmentos de classes nacionais em oposição e em competição a outras nações.

34. Fay e Stucker (1980) dirão que a autora levanta a questão correta, mas the dá uma resposta equivocada, quando partindo de uma abordagem deveras eurocentrista, não considera a estrutura básica desigual do sistema mundial, a divisão entre um centro acumulador e explorador e uma periferia não acumuladora e explorada. A ausência do olhar para a periferia faz com que a autora relegue a maioria dos países do mercado mundial, abarcando somente

a realidades das poucas potências centrais, o que acaba maculando sua abordagem do capitalismo como sistema mundial.

35. 0 ensaio de 1974 constitui pedra angular na teorização de Braunmühl (1974), tanto que foi traduzido pela o inglês, com algumas revisões (alguns trechos do artigo de 1976 são inseridos), sendo publicado em 1978, com 0 título On the analysis of the Bourgeoise Nation State within the World Market context. An attempt to develop a methodological and theoretical approach. Nesse momento, há o reconhecimento da doutrinadora como um dos expoentes principais da escola da derivação, irradiando seus cânones pelo mundo. Devido a seu impacto e a sua centra-

lidade no pensamento da autora, esse texto é retomado mediante sua tradução para o espanhol, a qual foi publicada em 1983, como Mercado mundial y Estado nación, viabilizando a porosidade das ideias pela América Latina.
A relevância dessa abordagem não foi de pronto captada pelos principais cânones teóricos, abrindo uma lacuna na teoria marxista sobre o assunto, a qual foi alvo preferencial de críticas $^{33}$. E mesmo entre aqueles que conferiram todo o mérito à pensadora pela abordagem sistemática, as contestações não foram poupadas ${ }^{34}$. Independentemente da repercussão gerada, o que por ora interessa é apontar os ensinamentos que ficaram.

Braunmühl, em consonância com a nova leitura de Marx, extrai das categorias da economia política e da própria forma do capital, bem como das relações de produção capitalistas, o entendimento das estruturas políticas que lhe são próprias, como o Estado. E vai além, voltando seu foco para as relações internacionais (em sentido amplo). O mercado mundial é o substrato do qual se extraem todas as categorias da crítica marxiana da economia política. É ao mesmo tempo a precondição e o resultado da produção capitalista. Asseverando o caráter intrinsecamente internacional do modo de produção capitalista, a base do Estado nacional só pode ser o mercado mundial; e este, por sua vez, só existe nos e a partir de espaços nacionalmente organizados. Em suma, é por meio da articulação entre a dinâmica contraditória de acumulação entre internacionalização e nacionalização dos capitais e da multiplicidade de Estados nacionais, singulares e em constante competição pela valorização do valor, que se podem extrair as entranhas constitutivas do imperialismo, a força edulcorante do sistema de Estados.

A despeito da originalidade das ideias, Braunmühl não legou uma obra condensada em um livro específico, mas inacabada, com pistas cintilantes nos seus três artigos seminais (e seus consequentes desdobramentos) ${ }^{35}$. Em virtude do curto tempo em voga e do redirecionamento dos estudos, a autora manteve-se voltada ao sistema internacional, mas alicerçada em outros pilares, não deixando uma trilha de continuidade nas reflexões sobre imperialismo. Ainda assim, foi responsável por pavimentar as bases para a reflexão sobre a sofisticação da teoria marxista do Estado e do imperialismo. Com essa mirada, ela descortinou um campo fértil para o debate das relações internacionais no capitalismo.

Referências

ALTVATER, Elmar; HOFFMANN, Jürgen. The west germany state derivation debate: the relation between economy and politics as a problem of marxist state theory. Social Text. n. 24, Duke University Press, 1990, p. 134-155.

ANDERSON, Perry. Considerações sobre o marxismo ocidental: nas trilhas do materialismo histórico. São Paulo: Boitempo, 2004

BARKER, Colin. A note on the theory of capitalist States. In: CLARKE, Simon (Ed.). The state debate. London: Palgrave Macmillan, 1991, p. 182-191.

BONEFELD, Werner; HOLLOWAY, John. Introduction: Post-Fordism and social form. In: BONEFELD, Werner e HOLOWAY, John. Post-Fordism \& social form: a marxist debate on the Post-Fordist State. London: Macmillan Academic and Professional LTD, 1991, p. 1-7.

BONEFELD, Werner. Más allá de las relaciones internacionales: acerca del mercado mundial y el estado-nación. In: KAN, Julián; PASCUAL, Rodrigo (Comp). Integrados (?): debates sobre las relaciones internacionales y la integración regional latino-americana y europea. Buenos Aires: Imago Mundi, 2013, p. 43-70. 
BONNET, Alberto. Estado y capital: debates sobre la derivación y la reformulación del Estado. In: THWAITES-REY, Mabel (Org). Estado y marxismo: un siglo y medio de debates. Buenos Aires: Prometeo Libros, 2007, p. 269-296.

BRAUNMÜHL, Claudia von. Weltmarktbewegung des kapitals, imperialismus und Staat. In: BRAUNMÜHL, Claudia von et al. Probleme einer materialistische staatstheorie. Frankfurt am Main: Suhrkamp, 1973, p. 11-91.

BRAUNMÜHL, Claudia von. Kapitalakkumulation im weltmarktzusammenhang. zum methodischen ansatz einer analyse des bürgelichen nationalstaats. In: ERBERLE, Friedrich (Org.). Gesellschaft: beiträge zur Marxschen theorie 1. Frankfurt am Main: Suhrkamp, 1974, p. 30-51.

BRAUNMÜHL, Claudia von. Die nationalstaatliche organisiertheit der bürgerlichen gesellschaft. ansatz zu einer historischen und systematischen untersuchung. In: ERBELE, Friedrich (Org.). Gesellschaft: beiträge zur Marxschen theorie 8/9, Frankfurt am Main: Suhrkamp, 1976, p. 273-334.

BRAUNMÜHL, Claudia von. On the analysis of the the bourgeois nation State within the world market context. In: HOLLOWAY, John; PICCIOTTO, Sol (Ed.). State and capital: a marxist debate. Londres: Edward Arnold, 1978, p. 160-177.

BRAUNMÜHL, Claudia von. Mercado mundial y Estado nación. Cuadernos Políticos, n. 35. México, D.F., Ediciones Era, p. 4-14, enero-marzo, 1983.

BUKHARIN, Nicolai. El imperialismo e la acumulación de capital. Buenos Aires: Editorial Tiempo Contemporaneo, 1974.

BUKHARIN, Nicolai. A economia mundial e o imperialismo. Tradução de Raul de Carvalho. São Paulo: Abril Cultural, 1986.

BUSCH, Klaus. Die multinationalen Konzerne- zur Analyse der Weltmarktbewegung des Kapitals. Frankfurt am Main: Suhrkamp Verlag, 1974.

CALDAS, Camilo Onoda Luiz. Teoria da derivação do Estado e do Direito. São Paulo: Outras Expressões; Dobra Univeritária, 2015.

CLARKE, Simon. The state debate. In: CLARKE, Simon (Ed.) The state debate. Londres: Palgrave Macmillan, 1991, p. 1-61.

CARNOY, Martin. Estado e teoria política. Campinas-SP: Papirus, 1994.

ELBE, Ingo. Marx im westen: die neue Marx-Lektüre in der Bundesrepublik seit 1965. Berlim : Akademie, 2010.

FAY, Margaret; STUCKEY, Barbara. A friendly critique of Claudia von Braunmühl's on the analysis of the Bourgeoise nation state within the world context: an attempt to develop a methodological and theorical approach. Kapitalistate: working papers on capitalist State. Berkeley, n 8, p. 138-147, 1980.

GERSTENBERG, Heide. The historical constitution of the political forms of capitalism. Antipode: A Radical Journal of Geography. New York, Wiley Blackwell, v. 43, n. 1, p. 60-86, 2010.

HIRSCH, Joachim. Teoria materialista do Estado: processos de transformação do sistema capitalista de Estados. Tradução de Luciano Cavini Martorano. Rio de Janeiro: Editora Revan, 2010.

HIRSCH, Joachim. Die toten Hunden wecken? Entrevista: Joachim Hirsch. Berlim:Arranca!,n. 24, 2002. Interview mit Joachim Hirsch zur Staatstheorie und Staatsableitung. Disponível em: $<$ http://arranca.org/ausgabe/24/tote-hunde-wecken>. Acesso em: 30 out. 2017.

HOLLOWAY, John; PICCIOTTO, Sol. Towards a materialist theory of the State. In: HOLLOWAY, John; PICCIOTTO, Sol (Ed.). State and capital: a Marxist debate. Londres: Edward Arnold, 1978, p. 1-31.

JESSOP, Bob. The capitalist state: marxist theories and methods. Oxford: Martin Robertson \& Co., 1982.

KÁN, Julián. Una relación particular: clase dominante, gobierno y orígenes del MERCOSUR. In: KAN, Julián; PASCUAL, Rodrigo (Comp). Integrados (?): debates sobre las relaciones internacionales y la integración regional latino-americana y europea. Buenos Aires: Imago Mundi, 2013, p. 155-204.

LEITE, Leonardo de Magalhães. O Capital no mundo e o mundo do Capital: uma reinterpretação do imperialismo a partir da teoria do valor de Marx. 2017. 352f. Tese. (Doutorado)- Programa de Pós-Graduação em Economia, Universidade Federal Fluminense, Niterói, 2017.

MARX, Karl. O capital: crítica da economia política: livro I: o processo de produção do capital. São Paulo: Boitempo, 2013. 
MARX, Karl. O capital: crítica da economia política: livro III: o processo global da produção capitalista. Tradução de Rubens Enderle. Edição de Friedrich Engels. São Paulo: Boitempo, 2017.

MASCARO, Alysson Leandro. Estado e forma política. São Paulo: Boitempo Editorial, 2013.

MOORE JÚNIOR, Barrington. Social origins of dictatorship and democracy: lord and peasant in the making of the modern world. Boston: Beacon Paperback, 1966.

MÜLLER, Wolfgang; NEUSÜSS, Christel. Die sozialstaatsillusion und der widerspruch von lohnarbeit und kapital: probleme des Klassenkampfs (PROKLA). Sonderrheft 1 Berlin, 1971, p. 7-70. Disponível em: <http://www.prokla.de/wp/wp-content/uploads/1971/Prokla-Sonderheft1.pdf >. Acesso em: 12 abr.2016.

MÜLLER, Wolfgang; NEUSÜSS, Christel. The Welfare-State Illusion and the contradiction between wage labour and capital. In: HOLLOWAY, John; PICCIOTTO, Sol (Ed). State and capital: a marxist debate. Londres: Edward Arnold, 1978, p. 32-39.

NACHTWEY, Oliver; TEN BRINK, Tobias. Lost in translation. the German world market debate in the 1970s. Historical Materialism, v.16, n.1, p. 37-70, 2008.

NEUSÜSS, Christel. Imperialismus und weltmarktbewegung des kapitals. Erlangen: Politladen, 1972 . 